\title{
Efisiensi Pemarasitan Parasitoid Trichogramma chilotraeae Nagaraja \& Nagarkatti (Hymenoptera:Trichogrammatidae) Pada Berbagai Jumlah Inang dan Kepadatan Parasitoid
}

\author{
HASRIYANTY ${ }^{1)}$, DAMAYANTI BUCHORI ${ }^{2)}$, PUDJLANTO $^{2)}$ \\ 1) Jurusan Hama dan Penyakit Tanaman, Fakultas Pertanian, \\ Universitas Tadulako Palu. ${ }^{2}$ Staf Pengajar Jurusan Proteksi Tanaman, \\ Fakultas Pertanian, Institut Pertanian Bogor
}

(diterima Juli 2007, disetujui Desember 2007)

\begin{abstract}
Parasitism Efficiency of egg Parasitoid Trichogramma chilotraeae Nagaraja \& Nagarkatti (Hymenoptera:Trichogrammatidae) in relation with host and Parasitoid desinty. The objective of the research was to study behaviour and efficiency parasitism of egg parasitoid Trichogramma chilotraeae in relation with host and parasitoid density under laboratory condition. Eggs of Corcyra cephalonica were used as a host for Trichogramma chilotraeae. Five different host (egg) densities: $3,6,12,24$ and 48 eggs were provided to one and two active female parasitoids $T$. chilotraeae. Percentage of parasitism, female progeny, and selfsuperparasitism were counted. Results showed that, host density was found to have a strong effect on parasitism percentage, female progeny percentage and selfsuperparasitism percentage. Two parameters, parasitism percentage, and selfsuperparasitism decreases with increasing number of host density, in contrast, female progeny percentage increase with increasing host density. Parasitoid density affected selfsuperparasitism and female progeny only on one level of host density ( 3 hosts) but not to all parameters of other density treatments.
\end{abstract}

KEYWORDS: Trichogramma chilotraeae, number of host, parasitoid density, parasitoid efficiency,

\section{PENDAHULUAN}

Pengendalian hayati merupakan suatu strategi pengendalian hama yang saat ini banyak dikembangkan untuk menggantikan penggunaan pestisida sintetik yang cenderung menimbulkan dampak negatif seperti resistensi dan resurgensi pada hama sasaran, munculnya hama sekunder, pencemaran lingkungan dan pengaruhnya pada kesehatan manusia, serta residu pada produk pertanian dan hewan. Pengendalian hayati diartikan sebagai kegiatan parasitoid, predator dan patogen yang memelihara, menjaga keseimbangan kepadatan polulasi suatu organisme lain pada suatu tingkat populasi rata-rata tanpa pengendalian lain (DeBach 1973).

Salah satu kelompok musuh alami serangga hama yang banyak dikembangkan adalah parasitoid. Para- 
sitoid umumnya merupakan serangga dari ordo Hymenoptera, Salah satu famili dari ordo Hymenoptera yang anggotanya banyak berperan sebagai parasitoid adalah famili Trichogrammatidae. Dalam Famili Trichogrammatidae terdapat 80 genera dan semuanya diketahui merupakan parasitoid telur (Pinto \& Stouthamer 1994). Dua genera yang terkenal adalah Trichogramma dan Trichogrammatoidea (Clausen 1940; Nagarkatti \& Nagaraja 1977). Selama 20 tahun terakhir parasitoid Trichogramma telah digunakan secara luas terutama untuk mengendalikan hama-hama pada tanaman pangan, misalnya pada padi jagung, gandum dan sorghum, pada tanaman industri; tebu, kapas dan kedelai, sayuran dan buah-buahan (Li 1994).

Penggunaan parasitoid telur Trichogramma dapat menjadi pilihan karena dapat mengendalikan hama pada fase paling awal sehingga kerusakan tanaman dapat dicegah sedini mungkin. Salah satu spesies parasitoid Trichogramma adalah $T$. chilotraeae. Parasitoid T. chilotraeae merupakan parasitoid telur yang diketahui menyerang beberapa hama Lepidoptera, termasuk Helicoverpa armigera (Nurindah \& Bindra 1989), Chillo suppersalis dan Ostrina furnacalis (Kalshoven 1981), juga merupakan spesies yang relative baru diketahui menyerang telur hama Plutella xylostella (Hasriyanty 2006).
Berkenaan dengan tujuan untuk memanfaatkan parasitoid $T$. chilotraeae ini, maka banyak aspek mendasar yang perlu dikaji. Efisiensi pemarasitan merupakan faktor yang penting untuk dikaji dalam kaitannya dengan kegiatan pembiakan massal, karena diketahui bahwa setiap spesies parasitoid Tricogrammatidae akan memiliki ciri-ciri biologi yang berbeda, demikian juga faktor lingkungan dalam hal ini kepadatan inang dan kepadatan parasitoid (foundres) akan berpengaruh pada biologi dan perilaku reproduksi yang nantinya akan menentukan kualitas parasitoid yang dihasilkan. Penelitian ini bertujuan untuk mempelajari efisiensi pemarasitan parasitoid $T$. chilotraeae pada berbagai jumlah inang dan kepadatan parasitoid.

\section{BAHAN DAN METODE}

\section{Waktu dan Tempat}

Penelitian ini dilaksanakan pada bulan Juni 2005 sampai dengan Februari 2006, bertempat di LaboOratorium Bioekologi Parasitoid dan Predator, Departemen Proteksi Tanaman, Fakultas Pertanian Institut Pertanian Bogor.

Koleksi dan Perbanyakan Parasitoid Serta Perbanyakan Serangga Inang Corcyra cephalonica

Parasitoid yang digunakan pada penelitian ini berasal dari areal pertanaman kubis di daerah Pangalengan Bandung. Koleksi 
parasitoid dilakukan dengan cara mengumpul kelompok-kelompok telur Plutella xylostella yang ada pada daun kubis menggunakan tangan (hand collection method). Telur yang terkumpul dibawa ke laboratorium dan diinkubasikan sampai parasitoid muncul dari telur yang terparasit. Parasitoid kemudian dikembangbiakkan pada telur inang pengganti Corcyra cephalonica. Parasitoid dari perbanyakan ini kemudian diidentifikasi dan dibiakkan lebih lanjut sebagai bahan penelitian.

Perbanyakan parasitoid dilakukan dengan cara menempelkan telur C.cephalonica menggunakan gom arabik pada suatu potongan karton (pias). Pias kemudian di-freezer selama 2 jam dengan tujuan untuk membunuh embrio dalam telur. Pias selanjutnya dimasukkan dalam tabung reaksi untuk dipaparkan pada parasitoid.

Perbanyakan inang pengganti C. cephalonica dilakukan dengan cara menempatkan imago jantan dan betina pada suatu tabung pembiakan berbentuk silinder dengan bagian tutup atas dan bawah terbuat dari kawat kasa 25 mesh, sebagai tempat imago betina nantinya meletakkan telur. Tabung selanjutnya ditempatkan pada kurungan kasa. Setiap hari telur yang dihasilkan dipanen, sebagian digunakan untuk bahan penelitian, sebagian untuk perbayakan parasitoid dan sebagian lainnya untuk perbanyakan $C$. cephalonica sendiri dengan cara menaburkannya telur pada wadah yang berisi campuran dedak dan pakan ayam.

\section{Studi Effisiensi Pemarasitan pada Berbagai Kepadatan Inang dan Kepadatan Parasitoid}

Parasitoid yang telah berumur 1 hari dan diperkirakan sudah berkopulasi ditempatkan pada tabung reaksi sesuai dengan perlakuan kepadatan parasitoid, yakni 1 dan 2 parasitoid. Sementara itu, pias (potongan karton yang berukuran $1 \times 4$ $\mathrm{cm})$ yang berisi telur inang dibuat dengan cara merekatkan inang yang jumlahnya sesuai dengan perlakuan yakni, 3, 6, 12, 24 dan 48. Pias kemudian dimasukkan kedalam tabung reaksi yang sudah berisi parasitoid dan dipaparkan selama tiga jam. Bila imago sudah keluar, kemudian diamati dibawah mikroskop untuk mengetahui kelamin keturunan yang dihasilkan. Parasitoid yang digunakan pada penelitian adalah keturunan F6 - F33

\section{Rancangan Percobaan dan Analisis Data :}

Rancangan percobaan yang digunakan adalah Rancangan Acak Lengkap (RAL) dengan lima perlakuan jumlah inang, yakni 3, 6, 12, 24 dan 48 inang, di paparkan pada 1 dan 2 induk parasitoid betina, perlakuan dilaksanakan dengan 20 ulangan.

Data jumlah inang terparasit, persentase inang terparasit, persentase 
keturunan betina dan persentase keturunan jantan yang dihasilkan dianalisis dengan ANOVA dan dilajutkan dengan uji Tuckey $\alpha 0,05$. Pengaruh kepadatan betina diuji menggunakan uji $t$. Pengolahan data menggunakan program Minitab.

\section{HASIL DAN PEMBAHASAN}

Hasil analisis sidik ragam menunjukan bahwa jumlah inang secara signifikan berpengaruh nyata terhadap total telur inang terparasit $(P$ $=0.000$ ). Jumlah inang terparasit semakin meningkat seiring bertambahnya inang (Tabel 1) baik pada pemaparan 1 parasitoid maupun pada pemaparan 2 parasitoid, meski demikian bila dilihat dari persentase inang terparasit dari total inang yang dipaparkan, menunjukkan bahwa pada perlakuan inang 48 , persentase inang terparasit sangat rendah, $46,25 \%$ pada pemaparan 1 parasitoid betina dan $65,52 \%$ pada pemaparan 2 parasitoid betina, dan hasil uji lanjut menunjukkan perlakuan inang 48 berbeda nyata dengan semua perlakuan lainnya (Tabel 1). Jadi berdasarkan hasil ini, untuk tujuan efisiensi pada perbanyakan massal maka rasio jumlah inang 24 dengan 1 betina lebih efisien dibandingkan dengan rasio inang 48 dengan 1 betina. Hasil tersebut sekaligus menunjukkan bahwa setiap individu parasitoid betina mempunyai kemampuan optimum untuk melakukan pemarasitan pada jangka waktu 3 jam.

Bila melihat data pada pemaparan 2 parasitoid betina, menunjukkan bahwa jumlah inang terparasit pada setiap perlakuan, memang lebih banyak dibanding pada pemaparan 1 parasitoid betina, tetapi berdasarkan uji $t$, ternyata hanya perlakuan 2 parasitoid 48 inang yang berbeda dengan perlakuan 1 parasitoid 48 inang. Meskipun berbeda nyata, tetapi parasitoid betina tidak mampu mengoptimalkan kemampuan memarasit secara optimum (dalam waktu 3 jam, total inang terparasit tidak menunjukkan angka 2 kali lipat angka pada pemarasitan 1 parasitoid betina), ini menunjukkan bahwa kehadiran betina lain akan mempengaruhi kegiatan parasitisme. Hasil sidik ragam menunjukkan bahwa perlakuan berbagai jumlah inang berpengaruh nyata terhadap persentase keturunan betina $(P=0.000)$ maupun keturunan jantan $(P=0.000)$ pada pemaparan 1 parasitoid betina, sedangkan pada pemaparan 2 parasitoid betina, jumlah inang berpengaruh nyata pada persentase keturunan betina $(P=$ 0.000 ) tetapi tidak berbeda nyata pada persentase keturunan jantan $(P=$ 0,210 ). Bertambahnya jumlah inang cenderung memberikan pengaruh pada perilaku induk betina untuk lebih banyak menghasilkan keturunan betina, meskipun dari hasil analisis menunjukkan bahwa perbedaan terjadi 
Tabel 1. Jumlah inang terparasit, persentase inang terparasit, persentase peletakan keturunan betina dan jantan pada berbagai jumlah inang dan kepadatan parasitoid.

\begin{tabular}{|c|c|c|c|c|c|}
\hline \multicolumn{2}{|c|}{ Perlakuan } & \multirow[b]{2}{*}{$\begin{array}{l}\text { Jumlah } \\
\text { inang } \\
\text { terparasit }\end{array}$} & \multirow[b]{2}{*}{$\begin{array}{c}\text { Persentase } \\
\text { Inang yang } \\
\text { terparasit } \\
x \pm \text { SD }\end{array}$} & \multirow{2}{*}{$\begin{array}{c}\text { Persentase } \\
\text { Peletakan } \\
\text { keturunan } \\
\text { betina } \\
\mathrm{x} \neq \mathrm{SD}\end{array}$} & \multirow{2}{*}{$\begin{array}{c}\text { Persentase } \\
\text { peletakan } \\
\text { keturunan } \\
\text { jantan } \\
x \pm S D\end{array}$} \\
\hline $\begin{array}{l}\text { Kepadatan } \\
\text { parasitoid/ } \\
\text { Inang }\end{array}$ & $\mathbf{n}$ & & & & \\
\hline \multicolumn{6}{|l|}{1 parasitoid } \\
\hline Inang 3 & 20 & 55 & $91,67 \pm 14,814 a$ & $60,84 \pm 9,79 a$ & $39,16 \pm 9,79 a$ \\
\hline Inang 6 & 20 & 104 & $86,67 \pm 11,60 a b$ & $65,33 \pm 17,24 a b$ & $23,92 \pm 11,49 b$ \\
\hline Inang 12 & 20 & 201 & $83,75 \pm 8,75 a b$ & $67,63 \pm 13,79 a b$ & $24,86 \pm 11,28 b$ \\
\hline Inang 24 & 20 & 388 & $81,04 \pm 9,41 b$ & $75,29 \pm 7,69 b$ & $21,11 \pm 8,04 b$ \\
\hline Inang 48 & 20 & 446 & $46,25 \pm 5,64 c$ & $76,87 \pm 5,73 b$ & $21,09 \neq 6,19 b$ \\
\hline \multicolumn{6}{|l|}{2 parasitoid } \\
\hline Inang 3 & 20 & 59 & $98,33=745 a$ & $49,17 \pm 16,65 a$ & $25,83 \pm 15,74 a$ \\
\hline Inang 6 & 20 & 110 & $91,67 \pm 10,12 a b$ & $65,92 \pm 18,10 b$ & $20,50 \pm 14,32 a$ \\
\hline Inang 12 & 20 & 217 & $90,42 \pm 6,77 b$ & $65,48 \pm 18,38 b$ & $17,32 \pm 12,34 \mathrm{a}$ \\
\hline Inang 24 & 20 & 378 & $78,75 \pm 7,144 c$ & $74,09 \pm 5,862 \mathrm{~b}$ & $20,11 \pm 4,94 a$ \\
\hline Inang 48 & 20 & 630 & $65,52 \pm 11,50 \mathrm{~d}$ & $75,35 \pm 5,67 \mathrm{~b}$ & $22,16 \pm 4,94 a$ \\
\hline
\end{tabular}

Ket: Pada masing-masing perlakuan kepadatan parasitoid, nilai rataan dan simpangan baku sekolom yang diikuti huruf yang sama tidak berbeda nyata berdasarkan uji Tuckey pada $a=0,05$

pada perlakuan jumlah inang rendah (3 inang) dibandingkan dengan perlakuan jumlah inang yang banyak ( 24 dan 48 inang) untuk pemaparan 1 parasitoid betina, sedangkan pada pemaparan 2 parasitoid betina, perlakuan 3 inang berbeda dengan semua perlakuan lainnya. Sebaliknya bertambahnya inang menyebabkan kecenderungan persentase peletakan keturunan jantan menjadi semakin berkurang. Berdasarkan hasil ini dapat dikatakan, secara umum parasitoid betina mempunyai perilaku untuk mengoptimalkan pemanfaatan sumberdaya yang ada untuk memaksimalkan kemampuan reproduksinya.

Bila dibandingkan antar perlakuan kepadatan betina, berdasarkan uji $t$, maka hanya perlakuan kepadatan 1 betina dengan jumlah inang 3 yang berbeda dengan perlakuan 1 betina dengan inang 3 pada parameter persentase keturunan betina maupun persentase keturunan jantan. Hasil ini menunjukkan bahwa pada keadaan inang rendah, adanya peningkatan kepadatan betina akan menyebabkan berkurangnya peletakan jumlah betina dan sebaliknya akan menambah peletakan keturunan jantan.

Secara umum bahwa pengamatan perilaku reproduksi bertujuan untuk lebih memahami perilaku apa yang dilakukan parasitoid untuk tujuan memaksimalkan keberhasilan reproduksi dan keberlangsungan keturunannya nanti, yang secara langsung memberikan arti penting untuk memperbaiki keefektifan pengendalian hama sasaran di lapangan dalam suatu program pengendalian hayati. 
KESIMPULAN DAN SARAN

\section{Kesimpulan}

1. Jumlah inang berpengaruh pada persentase inang terparasit, persentase peletakan keturunan betina dan keturunan jantan. Jumlah inang terparasit serta persentase keturunan betina semakin meningkat seiring bertambahnya jumlah inang, sebaliknya persentase inang terparasit semakin berkurang seiring bertambahnya jumlah inang.

2. Untuk tujuan efisiensi pada perbanyakan massal, maka rasio satu betina dengan 24 inang lebih efisien dibandingkan dengan rasio 1 betina 48 inang.

\section{DAFTAR PUSTAKA}

Clausen CP. 1940. Entomophagous Insect. New York and London: McGraw-Hill Book Company, Inc.

DeBach P. 1973. The scope of biological control. Di dalam: DeBach P, editor. Biological Control of Insect Pest and Weeds. London: Chapman and Hall LTD.

Godfray HCJ. 1994. Parasitoids : Behavioral and Evolutionary Ecology. New Jersey: Princenton University Press.
Li LY. 1994. Worldwide use of Trichogramma for biological control on different crops: a survey. Di dalam : Wajnberg E, Hassan SA, editor. Biological Control with Egg Parasitoids. Wallingford: $\mathrm{CAB}$ International.

Nagarkatti S, Nagaraja H. 1977. Biosystematics of Trichogramma and Trichogrammatoidea species. $J$ Ann. Rev. Entomol 22: 157-176.

Nurindah, Bindra OS. 1989. Studies on Trichogramma spp. (Hymenoptera : Trichogrammatidae) in the control of Heliothis armigera (Hubner) (Lepidoptera : Noctuidae). Biotrop. Spec. Publ. 36: 165-173.

Pinto DJ, Stouthamer R. 1994. Systematics of the Trichogrammatidae with emphasis on Trichogramma. Di dalam: Wajnberg E, Hassan SA, editor. Biological Control With Egg Parsitoids. Wallingford: $\mathrm{CAB}$ International.

Schmidt JM. 1994. Host recognition and acceptance by trichogramma. . Di dalam : Wajnberg E, Hassan SA, editor. Biological Control with Egg Parasitoids. Wallingford: CAB International.

Wajnberg 1993. Genetic variation in sex allocation in parasitic wasp: variation in sex pattern with sequence of oviposition. $J$ Entomolol Experimentalis et Applicata 69: 221-229.

Wajnberg E. 1994. Intra population genetic variation in Trichogramma. Di dalam: Wajnberg E, Hassan SA, editor. Biological Control With Egg Parasitoids. Wallingford: $\mathrm{CAB}$ International. 